\title{
Scirrhous eosinophilic gastritis in two dogs
}

\author{
Gastrite eosinofílica esquirrosa em dois cães
}

\author{
Cláudio João Mourão Laisse ${ }^{\mathrm{I}}$ Neusa Barbosa Castro ${ }^{\mathrm{I}}$ Eduardo Conceição de Oliveira ${ }^{\mathrm{I}}$ \\ Matheus Viezzer Bianchi Gabriela Fredo ${ }^{I}$ Amanda dos Santos Siviero ${ }^{I I}$ Daniela Jardim Lopes ${ }^{\text {II }}$ \\ Saulo Petinatti Pavarini ${ }^{I}$ David Driemeier ${ }^{I}$ Luciana Sonne $^{I^{*}}$
}

\section{ABSTRACT}

Scirrhous eosinophilic gastritis (SEG) is characterized by diffuse infiltration of eosinophils and concomitant fibrovascular tissue proliferation in the stomach wall. The condition is a rare occurrence with an unknown cause. Two dogs were examined with a history of progressive weight loss, emesis, melena and anorexia. Complete blood cell counts of both cases revealed anemia and eosinophilia, while ultrasonography examination revealed thickening of the stomach wall. Due to suspected gastric neoplasia and a poor clinical prognosis, the dogs were euthanized. At necropsy, both had markedly distended stomachs with a diffusely thickened and firm wall. The spleens of both dogs were enlarged with a nodular surface. Histological evaluation revealed diffuse infiltrate of eosinophils, fibrovascular tissue proliferation and fibrinoid degeneration in blood vessel walls of stomach and spleen. SEG is a rare pathological condition that must be considered as a possible diagnosis in dogs presenting gastrointestinal signs and eosinophilia.

Key words: dog, eosinophilia, gastroenteritis, gastropathy.

RESUMO

A gastrite eosinofilica esquirrosa (GEE) é caracterizada por infiltrado inflamatório difuso de eosinófilos e concomitante proliferação de tecido fibrovascular no estômago. A condição apresenta ocorrência rara e causa desconhecida. Dois cães foram examinados com histórico de emagrecimento progressivo, êmese, melena e anorexia. O hemograma de ambos os casos revelou anemia e eosinofilia, enquanto o exame ultrassonográfico evidenciou espessamento da parede do estômago. Diante de suspeita de neoplasia gástrica e devido ao prognóstico desfavorável, foi realizada a eutanásia dos cães. $\mathrm{Na}$ necropsia, ambos apresentavam estômago acentuadamente aumentado, com parede difusamente espessada e firme. $O$ baço dos dois cães apresentava-se aumentado e com superfície nodular. O exame histopatológico revelou infiltrado difuso de eosinófilos, proliferação de tecido fibrovascular e degeneração fibrinoide na parede de vasos sanguíneos no estômago e baço. A GEE é uma condição patológica rara que deve ser considerada no diagnóstico em cães que apresentem sinais gastrointestinais e eosinofilia.

Palavras-chave: cão, eosinofilia, gastroenterite, gastropatia.

Eosinophilic gastroenteritis (EG) is a rare condition of unknown cause characterized by diffuse infiltration of eosinophils in the gastrointestinal tract (HSU \& LO, 1998). EG is frequently reported in humans (MORETTI et al., 2006; ZHOU et al., 2014) with few reports in dogs (MCTAVISH, 2002; FONSECA-ALVES et al., 2012). The condition can affect multiple segments of the digestive system concomitantly or individually, causing distinct gastrointestinal clinical manifestations (HSU \& LO, 1998; MCTAVISH, 2002; TEMIZ et al., 2012; FONSECA-ALVES et al., 2012). Scirrhous eosinophilic gastritis (SEG) is a subtype of EG characterized by diffuse infiltration of eosinophils and concomitant fibrous tissue proliferation in the stomach wall (HAYDEN \& FLEISCHMAN, 1977). The condition has unknown cause, and there are few studies describing this type of EG in dogs (HAYDEN \& FLEISCHMAN, 1977). Dogs affected by SEG show clinical signs similar to those presented by dogs with chronic gastrointestinal diseases (MCTAVISH, 2002). This report describes

\footnotetext{
ISetor de Patologia Veterinária (SPV), Universidade Federal do Rio Grande do Sul (UFRGS), Av. Bento Gonçalves, 9090, 91540-000, Porto Alegre, RS, Brasil. E-mail: lusonne@yahoo.com.br. "Corresponding author.

IHospital de Clínicas Veterinárias, Faculdade de Veterinária, Universidade Federal do Rio Grande do Sul (UFRGS), Porto Alegre, RS, Brasil. 
the clinical signs, laboratory results and pathological findings of SEG in two dogs.

Dog 1 was a two-year-old male, Fila Brasileiro breed, with a history of hyporexia, progressive weight loss, diarrhea and hematochezia for two months. On clinical examination, the dog presented marked cachexia, apathy and melena. The blood cell count revealed marked eosinophilia $\left(4936 \mathrm{~mm}^{-3}\right.$, reference values (RV): 100 to $\left.1240 \mathrm{~mm}^{-3}\right)$, marked decreased hemoglobin $(3.8 \mathrm{~g}$ $\mathrm{dL}^{-1}, \mathrm{RV}: 12$ to $\left.18 \mathrm{~g} \mathrm{dL}^{-1}\right)$ and decreased hematocrit (15\%, RV: 37 to 55\%). Serum biochemistry showed reduced albumin $\left(15.33 \mathrm{~g} \mathrm{~L}^{-1}, \mathrm{RV}: 26\right.$ to $\left.33 \mathrm{~g} \mathrm{~L}^{-1}\right)$. Abdominal ultrasonography examination revealed thickening of the gastric wall $(2.8 \mathrm{~cm})$, and the spleen was enlarged and multinodular with irregular borders. Dog 2 was a six year old male, mixed-breed, with a history of weight loss, anorexia and vomiting for 30 days and melena for three days. On physical examination the dog presented marked cachexia, dehydration and pale mucous membranes. Blood cell count revealed eosinophilia $\left(2400 \mathrm{~mm}^{-3}\right)$, decreased hemoglobin $\left(10.8 \mathrm{~g} \mathrm{dL}^{-1}\right)$ and decreased hematocrit (31\%). Abdominal ultrasonography revealed that the gastric wall was $1.9 \mathrm{~cm}$ thick, and the spleen was enlarged with irregular borders. Based on the clinical and ultrasonography examination in both of the cases, a presumptive diagnosis of gastric neoplasia or chronic gastritis was established. Euthanasia was performed in both of the cases due to a deteriorating quality of life and poor prognosis.

The dogs were necropsied, and the tissue samples were collected and fixed in $10 \%$ neutral buffered formalin, embedded in paraffin, sectioned at $5 \mu \mathrm{m}$, and stained with hematoxylin and eosin (HE). Sections of the stomach and spleen were also stained with Masson's trichrome (MT), Periodic acid-Schiff (PAS) and Grocott's methenamine silver (GMS).

At necropsy, both of the dogs presented similar lesions. The stomach was markedly enlarged with hemorrhages on the serosa (Figure 1A), and the stomach wall was diffusely thickened (2 to $4 \mathrm{~cm})$. On the cut surface the gastric wall was firm, white to yellow with multifocal small cystic areas (Figure 1B). The gastric mucosa presented multiple ulcerations ranging from 0.2 to $1 \mathrm{~cm}$ in diameter. The spleens were markedly enlarged, showing a multinodular aspect with white, firm tissue on the capsule (Figure 1C). The other viscera were normal.

Histological evaluation of the stomach of both dogs revealed transmural eosinophilic infiltration, which was severe in the mucosa and submucosa layers and mild in the muscular and serosa layers. The submucosa also presented marked fibrous connective tissue proliferation (evidenced with MT stain) and neovascularization (Figure 1D-E). Dog 1's stomach also presented discrete mast cells and Mott cell infiltration, multifocal areas of necrosis in the mucosa with neutrophil infiltration and fibrinoid necrosis of submucosal arteries (evidenced by PAS stain). Splenic lesions consisted of connective fibrous tissue proliferation, multifocal areas of hemorrhage, arterial fibrinoid necrosis and moderate multifocal infiltrating inflammatory cells composed of numerous eosinophils, moderate plasma cells, foamy macrophages and Mott cells (Figure 1F). Mild eosinophilic infiltration in the duodenum and liver of dog 1 was also observed. The GMS stain did not show fungal structures in the stomach and spleen of either dog 1 or 2 .

SEG is a subtype of EG that affects dogs and is a rare occurrence with few cases described (HAYDEN \& FLEISCHMAN, 1977). The diagnosis of SEG in the cases reported here was based on clinical signs, blood count, ultrasonography examination, necropsy and histopathological findings (HSU \& LO, 1998; FONSECA-ALVES et al., 2012).

In humans, EG is defined based on the following criteria: 1) gastrointestinal tract symptoms; 2) eosinophilic infiltration in the gastrointestinal tract (more than 20 eosinophils per high power field); and 3 ) exclusion of other general causes of eosinophilia (parasitic infestations, connective tissue disease, hypereosinophilic syndrome, lymphoma and other intestinal tumors, primary amyloidosis and celiac disease (HSU \& LO, 1998; PENNINCK, 2005). Clinical signs, laboratory test results and post-mortem findings of both cases reported are according to the criteria above mentioned.

The cause of EG is not elucidated; however, food allergens, hypersensitivity reactions and parasite migration are suggested as etiologies in dogs (HAYDEN \& FLEISCHMAN, 1977; FONSECAALVES et al., 2012). Some of the gastrointestinal parasites that may cause EG in humans and dogs are Ancylostoma caninum, Ascaris lumbricoides, Trichuris trichiura and Toxocara canis (HONG et al., 2003; CHIRA et al., 2005). Dog's owners reported no history of hypersensitivity reactions, and the dogs did not present gastrointestinal parasites at necropsy. The etiology of SEG in these cases thus remains uncertain.

Clinical signs presented by the dogs corroborate with those previously reported in other cases of EG in dogs (MCTAVISH, 2002; FONSECAALVES et al., 2012). Vomiting, weight loss and abdominal discomfort are usually observed early in the disease course, while tenesmus, hematochezia 


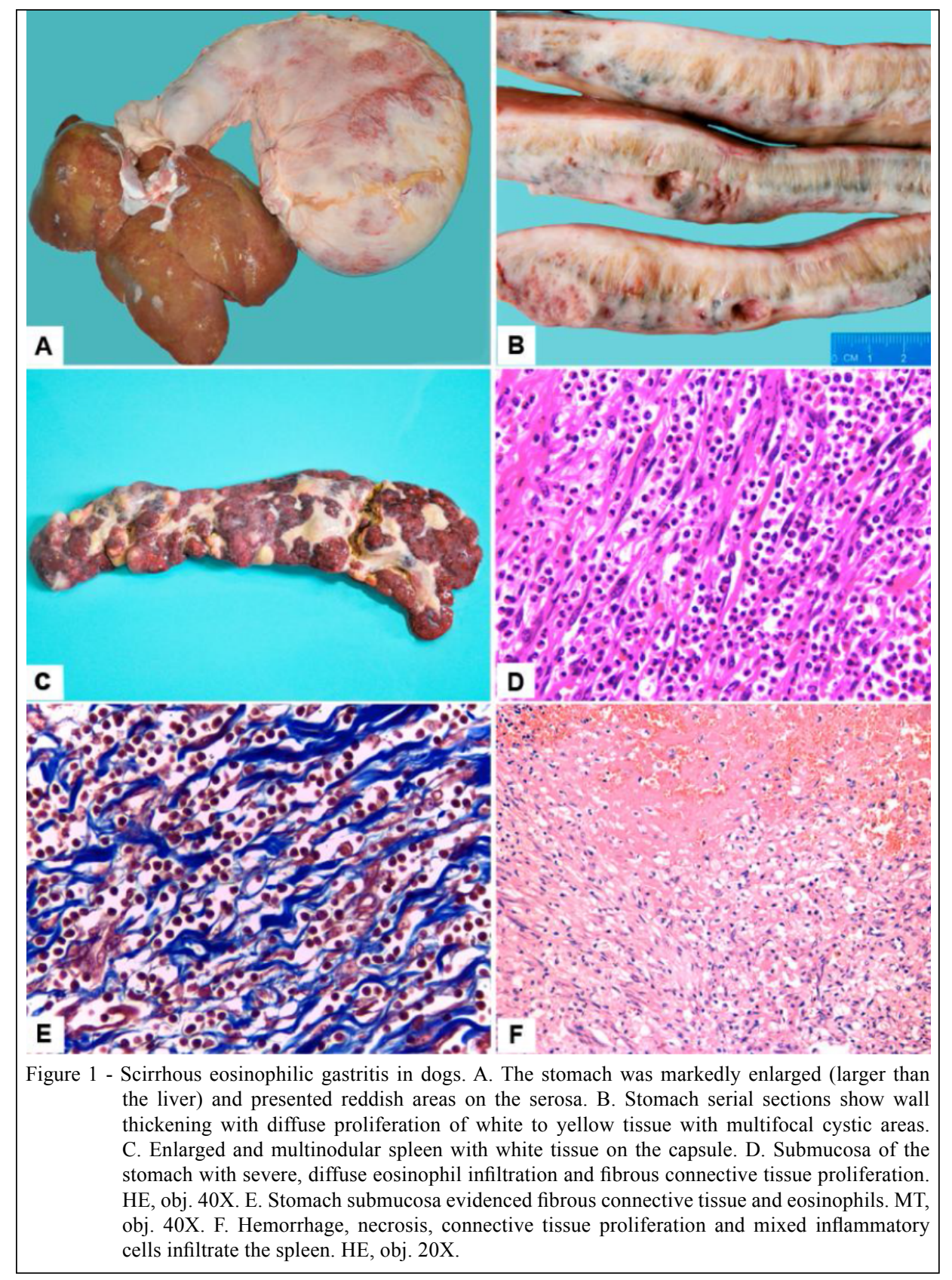

and melena are observed in the latter stages as the disease progresses. In both cases reported here, the hematochezia and melena resulted in anemia, which was severe in $\operatorname{dog} 1$ because it was presented to the veterinary in a later stage of the disease, presenting severe gastric ulcers. Based on the clinical and ultrasound examination, in both cases the presumptive diagnosis was gastric neoplasm. When there is a marked thickening of the gastric wall, inflammatory diseases of the gastrointestinal tract may mimic infiltrative neoplasms (PENNINCK, 2005).
Hypereosinophilia is a common finding in cases of EG in humans and dogs (HSU \& LO., 1998; MORETTI et al., 2006; TEMIZ et al., 2012; FONSECA-ALVES et al., 2012). Low albumin levels in the blood of dog 1 may be associated with the loss of appetite, vomiting and malabsorption due to gastric lesions.

In other cases of SEG, the gastric wall thickness ranged from 2 to $2,5 \mathrm{~cm}$ (HAYDEN \& FLEISCHMAN, 1977). In both dogs, the stomach wall was diffusely thickened, affecting the 
cardiac, fundic and pyloric regions. HAYDEN \& FLEISCHMAN (1977) and RODRÍGUEZ et al. (1995) reported marked thickening in the fundic region, while FONSECA-ALVES et al. (2012) found that the stomach wall was only thickened in the pyloric region. As in the cases we report, HAYDEN \& FLEISCHMAN (1977) described an enlarged and nodular spleen; however, the splenic lesion physiopathology is not clear.

Histologically, eosinophilic infiltration was observed in the stomach, spleen ( $\operatorname{dog} 1$ and 2), duodenum and liver (dog 1). The stomach and duodenum are the most affected gastrointestinal segments in the cases of EG in dogs and humans (HAYDEN \& FLEISCHMAN, 1977; MORETTI et al., 2006; FONSECA-ALVES et al., 2012). Eosinophil infiltration in the gastrointestinal tract is mainly observed in the mucosa and submucosa (25-100\%) followed by the muscle layers (13-70\%) and serosa (10-40\%) (KHAN, 2005). In humans, EG is histologically classified into mucosal, muscular, and subserosal (RODRÍGUEZ et al., 1995). In the cases described, the stomach lesions were transmural.

In this report, EG was classified as "scirrhous" due to the marked fibrovascular tissue proliferation observed in the gastric wall (HAYDEN \& FLEISCHMAN, 1977). SEG should be considered in the differential diagnosis of tumor-like lesions that present eosinophil infiltration in the stomach wall including gastric pythiosis (TROST et al., 2009) and gastric mast cell tumors. The diagnosis of gastric pythiosis was excluded because no fungal structures were observed upon GMS staining. The stomach of dog 1 presented some mast cell infiltration, but these cells did not present malignant features. Histopathological examination allowed the differentiation of SEG from other disorders that cause gastrointestinal signs and stomach wall thickening associated with eosinophil infiltration in dogs.

\section{ACKNOWLEDGMENTS}

To Conselho Nacional de Desenvolvimento Científico e Tecnológico (CNPq) and Coordenação de Aperfeiçoamento de Pessoal de Nível Superior (CAPES).

\section{REFERENCES}

CHIRA, O. et al. Eosinophilic ascites in a patient with Toxocara canis infection. A case report. Romanian Journal Of Gastroenterology, v.14, p.397-400, 2005. Available from: <http:// www.jgld.ro/2005/4/397-400_12.pdf >. Accessed: Sept. 26, 2015.
FONSECA-ALVES, C.E. et al. Eosinophilic gastroenteritis in basset hound dog. Open Journal of Animal Sciences, v.2, n.2, p.110-112, 2012. Available from: <http://dx.doi.org/10.4236/ojas.2012.22015>. Accessed: Oct. 20, 2014. doi: 10.4236/ojas.2012.22015.

HAYDEN, D.W.; FLEISCHMAN, R.W. Scirrhous eosinophilic gastritis in dogs with gastric arteritis. Veterinary Pathology, v.14, n.5, p.441-448, 1977. Available from: <http://vet.sagepub. com/content/14/5/441.long $>$. Accessed: Oct. 20, 2014. doi: $10.1177 / 030098587701400503$.

HONG, S. et al. A case of gastroenteritis associated with gastric trichuriasis. Journal of Korean Medical Science, v.18, p.429432, 2003. Available from: <http://www.ncbi.nlm.nih.gov/pmc/ articles/PMC3055056/pdf>. Accessed: Sept. 26, 2015.

HSU, Y.Q.; LO, C.Y.F. A case of eosinophilic gastroenteritis. Hong Kong Medical Journal, v.4, n.2, p.226-228, 1998. Available from: <http://www.hkam.org.hk/publications/hkmj/ article_pdf $>$. Accessed: Oct. 20, 2014.

KHAN, S. Eosinophilic gastroenteritis. Best Practice Research in Clinical Gastroenterology, v.19, n.2, p.177-198, 2005. Available from: <http://www.sciencedirect.com>. Accessed: Jan. 25, 2015. doi: 10.1016/j.bpg.2005.01.009.

MCTAVISH, S. Eosinophilic gastroenteritis in a dog. Canadian Veterinary Journal, v.43, n.6, p.463-465, 2002. Available from: <http://www.ncbi.nlm.nih.gov/pmc/articles/PMC339300/pdf>. Accessed: Oct. 20, 2014.

MORETTI, M.P. et al. Eosinophilic gastroenteritis: a case report. Arquivos Catarinenses de Medicina, v.35, n.4, p.104-107, 2006. Available from: <http://www.acm.org.br/revista/pdf/artigos/401. pdf $>$. Accessed: Oct. 20, 2014.

PENNINCK, D.G. Trato gastrintestinal. In: NYLAND, T.G.; MATTOON, J.S. (Eds). Ultra-som diagnóstico em pequenos animais. São Paulo: Roca, 2005. p.211-234.

RODRÍGUEZ, A. et al. Eosinophilic gastroenteritis syndrome in a dog. Veterinary Quarterly, v.17, p.34-36, 1995. Available from: $<$ http://www.tandfonline.com/toc/tveq20/17/1>. Accessed: Sept. 26, 2015. doi: 10.1080/01652176.1995.9694527.

TEMIZ, T. et al. Eosinophilic gastroenteritis: a rare case report. North American Journal of Medical Sciences, v.4, n.8, p.367368, 2012. Available from: <http://www.ncbi.nlm.nih.gov/ pmc/articles/PMC3421918/>. Accessed: Feb. 23, 2015. doi: 10.4103/1947-2714.99522.

TROST, M.E. etal. Clinical, morphologic and immunohistochemical aspects of canine gastrintestinal pythiosis. Pesquisa Veterinária Brasileira, v.29, n.8, p.673-679, 2009. Available from: <http:// www.scielo.br/pdf/pvb/v29n8/a12v29n8.pdf>. Accessed: Jul. 7, 2015. doi: 10.1590/S0100-736X2009000800012.

ZHOU, H.C. et al. Eosinophilic gastroenteritis with involvement of the urinary bladder. Pediatric Radiology, v.44, n.11, p.14541457, 2014. Available from: <http://download.springer.com/static/ pdf/254/art\%253A10>. Accessed: Feb. 23, 2015. doi: 10.1007/ s00247-014-3012-2. 